\title{
Review: Analysis and Benefit of Shells Content of Freshwater and Land Snails from Gastropods Class
}

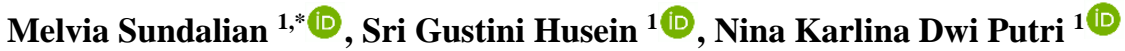 \\ 1 Sekolah Tinggi Farmasi Indonesia, Bandung, Indonesia; melviasundalian@stfi.ac.id (M.S.); srigustini@stfi.ac.id (S.G.H.); \\ dninakarlinap@gmail.com (N.K.D.P.); \\ * Correspondence: melviasundalian@stfi.ac.id (M.S.)
}

Scopus Author ID 57212552414

Received: 6.03.2021; Revised: 5.04.2021; Accepted: 10.04.2021; Published: 20.04.2021

\begin{abstract}
Gastropods are the largest class of phylum mollusks. Members of this class include land snails, sea snails, freshwater snails, land snails, and limpet. In some countries, snails are often processed to be food. Along with the high consumption of snail meat, their shells' disposal rate, which can become waste on land and waters, is also high. This study aimed to determine the analysis method and benefits of the chemical compound content of several freshwater and land snail shells from the gastropod class. The method in this review was literary search from national and international journals. The result is known that the snail shell contains major chemical compounds, namely $\mathrm{CaCO}_{3}$, chitin, and chitosan. In addition, there are other minor compounds, such as minerals zinc, iron, copper, phosphorus, manganese, sodium, potassium, and proximate data. These compounds can be used as biomaterials that are useful for the world of health. Instruments for analysis of chitin and chitosan compounds can use FTIR spectrophotometry and mineral compounds of $\mathrm{CaCO}_{3}$ also; other minerals can use AAS and XRF.
\end{abstract}

Keywords: chitin; chitosan; calcium carbonate; benefits; analysis; heavy metal; analysis proximate.

(C) 2021 by the authors. This article is an open-access article distributed under the terms and conditions of the Creative Commons Attribution (CC BY) license (https://creativecommons.org/licenses/by/4.0/).

\section{Introduction}

Gastropods are the largest class of phylum Mollusca. This class includes land snails, sea snails, freshwater snails, land snails, and limpets [1]. In some countries, freshwater snails and ground snails are often managed for their meat as food. In France, food processing from this snail is known as escargot. European states such as France, Portugal, Sardinia, and Spain provide this food as a menu "hors-d'oeuvre" or appetizer. Markets around the Cameroon area and restaurants in other parts of Nigeria and Africa are even experiencing increased demand for snail meat availability in their diet [2-4]. Furthermore, for the Asian region, there are China, Hong Kong, Japan, Thailand, Taiwan, and Indonesia, which often manage snail meat into food [5-8].

The snails' meat is high in protein and low in fat [3, 9-11]. Along with the high consumption of snail meat, the level of disposal of its shells which can become waste on land and waters, is also high [2,3], or some use it as animal feed and accessories (bracelets, necklaces, and wall ornaments or aquariums), but these efforts have not yet too high economic uses.

Based on several studies, it has been conducted to determine the potential value of the benefits of snail shell waste in the health world, including can be useful as hydroxyapatite $[12,13]$, collagen [14], active medicinal substances such as antibacterial, antimicrobial, 
antioxidant, pharmaceutical additives such as stabilizers, emulsifiers, thickening agents in the food industry [8,15-19], absorbers of compounds metals [20,21], and water bioindicators of polluting iron compounds [22]. This is because the snail shell contains active chemical compounds such as chitin $\left(\mathrm{C}_{8} \mathrm{H}_{13} \mathrm{NO}_{5}\right) \mathrm{n}$, which is the main organic material for the manufacture of chitosan $\left(\mathrm{C}_{6} \mathrm{H}_{11} \mathrm{NO}_{4}\right)$ n $[23,24]$, calcium carbonate $\left(\mathrm{CaCO}_{3}\right)$. The shell's main constituent ingredients $[25,26]$, other mineral content, and the composition of proximate compounds $[27,28]$. These compounds can be used as biomaterials that are useful for the world of health. Biomaterials themselves are substances derived from natural or synthetic sources used as medical devices and can interact with biological systems [29].

The content of active chemical compounds snail shells that can be found in nature varies depending on the source, such as the influence of the living place's mineral content, protein, and microorganisms. Seeing the great potential of the use of snail shell waste, writing a review of this journal aims to provide some information regarding the active chemical compound content of several gastropod-class freshwater snail shells that can be used as a reference basis to be made into biomaterials for raw materials for pharmaceutical drug preparations.

\section{Materials and Method}

This review's writing is compiled based on studies related to the analysis of active chemical compounds and the benefits contained in freshwater snail shells and gastropod class soil. The materials used are primary data, namely international and national journals, and secondary data sources taken from research reports and scientific articles. The number of literature reviewed is 55 journals. The search references in review journals presented here are taken from Science Direct, Google Scholar, Elsevier, Pubmed PMC, BioOne, and other journal websites. The research was conducted in Indonesian and English. The keywords used in the literature search included concentration chitin or chitosan of gastropods, the concentration of calcium carbonate of gastropods, shell freshwater snail, biomaterials, analysis, benefits, eaten snails.

\section{Results and Discussion}

\subsection{Analysis method.}

A series of analysis processes can determine the content of active chemical compounds found in snail shells. The components of the proximate composition, mineral, chitin and chitosan compounds in the snail shells have different analysis processes, from treatment to analysis using instruments. In addition, chitin and chitosan compounds based on research on gastropod class snail shells from different species have other differences: solvent concentration, type of solvent, temperature, and time. And for $\mathrm{CaCO}_{3}$ compounds, there are differences in temperature and time during the calcination process. The analysis method and the chemical compound content obtained can be seen in detail in Tables 1 and 2.

Table 1. Identification of chemical compounds in snail shell of gastropods class.

\begin{tabular}{|c|c|c|c|c|c|c|c|}
\hline \multirow{2}{*}{$\begin{array}{l}\text { Chemical } \\
\text { Compounds }\end{array}$} & \multirow[t]{2}{*}{ Species Name } & \multicolumn{4}{|c|}{ Test Conditions } & \multirow{2}{*}{$\begin{array}{c}\text { Identification } \\
\text { Method } \\
\text { (Instrument) }\end{array}$} & \multirow[t]{2}{*}{ Ref. } \\
\hline & & Treatment & Solvent & Temperature & Time & & \\
\hline \multirow[t]{4}{*}{ Chitin } & \multirow{3}{*}{$\begin{array}{l}\text { Achatina } \\
\text { achatina }\end{array}$} & Deproteinized & $1 \mathrm{~N} \mathrm{NaOH}$ & Boiled & 10 minutes & \multirow[t]{3}{*}{ FTIR } & \multirow[t]{3}{*}{ [30] } \\
\hline & & Demineralised & $6 \mathrm{~N} \mathrm{HCl}$ & $20^{\circ} \mathrm{C}$ & 10 minutes & & \\
\hline & & Decolorization & - & - & - & & \\
\hline & & Deproteinized & $1 \mathrm{~N} \mathrm{NaOH}$ & Boiled & 10 hour & FTIR & [30] \\
\hline
\end{tabular}




\begin{tabular}{|c|c|c|c|c|c|c|c|}
\hline \multirow{16}{*}{$\begin{array}{l}\text { Chemical } \\
\text { Compounds }\end{array}$} & \multirow{4}{*}{$\begin{array}{l}\text { Species Name } \\
\text { Archachatina } \\
\text { marganita }\end{array}$} & \multicolumn{4}{|c|}{ Test Conditions } & \multirow{4}{*}{$\begin{array}{c}\text { Identification } \\
\text { Method } \\
\text { (Instrument) }\end{array}$} & \multirow[t]{4}{*}{ Ref. } \\
\hline & & Treatment & Solvent & Temperature & Time & & \\
\hline & & Demineralised & $6 \mathrm{~N} \mathrm{HCl}$ & $20^{\circ} \mathrm{C}$ & 10 minutes & & \\
\hline & & Decolorization & - & - & - & & \\
\hline & \multirow{3}{*}{$\begin{array}{c}\text { Achatina } \\
\text { fulica }\end{array}$} & Deproteinized & $3.5 \% \mathrm{NaOH}$ & $65^{\circ} \mathrm{C}$ & 2 hour & \multirow[t]{3}{*}{ FTIR } & \multirow[t]{3}{*}{ [31] } \\
\hline & & Demineralised & $1 \mathrm{~N} \mathrm{HCl}$ & $40^{\circ} \mathrm{C}$ & 30 minutes & & \\
\hline & & Decolorization & $0.315 \% \mathrm{NaOCl}$ & $40^{\circ} \mathrm{C}$ & 1 hour & & \\
\hline & \multirow{3}{*}{$\begin{array}{c}\text { Nerita } \\
\text { crepidularia }\end{array}$} & Deproteinized & $1 \mathrm{~N} \mathrm{NaOH}$ & $80^{\circ} \mathrm{C}$ & 24 hour & \multirow[t]{3}{*}{ FTIR } & \multirow[t]{3}{*}{ [14] } \\
\hline & & Demineralised & $2 \mathrm{~N} \mathrm{HCl}$ & $25-30^{\circ} \mathrm{C}$ & 24 hour & & \\
\hline & & Decolorization & - & - & - & & \\
\hline & \multirow{3}{*}{$\begin{array}{c}\text { Pila } \\
\text { ampullacea }\end{array}$} & Deproteinized & $3.5 \% \mathrm{NaOH}$ & $60-70^{\circ} \mathrm{C}$ & 4 hour & \multirow[t]{3}{*}{ FTIR } & \multirow[t]{3}{*}{ [32] } \\
\hline & & Demineralised & $1.5 \mathrm{M} \mathrm{HCl}$ & $60-70^{\circ} \mathrm{C}$ & 4 hour & & \\
\hline & & Decolorization & - & - & - & & \\
\hline & \multirow{3}{*}{$\begin{array}{c}\text { Pomacea } \\
\text { canaliculata }\end{array}$} & Deproteinized & $2 \mathrm{M} \mathrm{NaOH}$ & $25-30^{\circ} \mathrm{C}$ & 2 hour & \multirow{3}{*}{$\begin{array}{l}\text { FTIR and } \\
\text { XRD }\end{array}$} & \multirow[t]{3}{*}{ [33] } \\
\hline & & Demineralised & $2 \mathrm{M} \mathrm{HCl}$ & $25-30^{\circ} \mathrm{C}$ & 2 hour & & \\
\hline & & Decolorization & - & - & - & & \\
\hline \multirow[t]{6}{*}{ Chitosan } & $\begin{array}{l}\text { Achatina } \\
\text { achatina }\end{array}$ & Deacetylation & $50 \% \mathrm{NaOH}$ & $100^{\circ} \mathrm{C}$ & 4 hour & FTIR & [30] \\
\hline & $\begin{array}{c}\text { Archachatina } \\
\text { marginata }\end{array}$ & Deacetylation & $50 \% \mathrm{NaOH}$ & $100^{\circ} \mathrm{C}$ & 4 hour & FTIR & [30] \\
\hline & $\begin{array}{c}\text { Achatina } \\
\text { fulica }\end{array}$ & Deacetylation & $60 \% \mathrm{NaOH}$ & $110^{\circ} \mathrm{C}$ & 1 hours & FTIR & [31] \\
\hline & $\begin{array}{c}\text { Nerita } \\
\text { crepidularia }\end{array}$ & Deacetylation & $40 \% \mathrm{NaOH}$ & $110^{\circ} \mathrm{C}$ & 6 hours & FTIR & [14] \\
\hline & $\begin{array}{c}\text { Pila } \\
\text { ampullacea }\end{array}$ & Deacetylation & $50 \% \mathrm{NaOH}$ & $100-110^{\circ} \mathrm{C}$ & 4 hours & FTIR & [32] \\
\hline & $\begin{array}{c}\text { Pomacea } \\
\text { canaliculata }\end{array}$ & Deacetylation & $50 \% \mathrm{NaOH}$ & $140^{\circ} \mathrm{C}$ & 2 hours & $\begin{array}{c}\text { FTIR and } \\
\text { XRD }\end{array}$ & [33] \\
\hline
\end{tabular}

Table 2. Identification of mineral content in snail shell of gastropods class.

\begin{tabular}{|c|c|c|c|c|c|c|}
\hline \multirow{2}{*}{$\begin{array}{l}\text { Chemical } \\
\text { Content }\end{array}$} & \multirow[b]{2}{*}{ Species Name } & \multicolumn{3}{|c|}{ Test Conditions } & \multirow{2}{*}{$\begin{array}{c}\text { Method of } \\
\text { Analysis } \\
\text { (Instrument) }\end{array}$} & \multirow[b]{2}{*}{ Ref. } \\
\hline & & Treatments & Temperature & Time & & \\
\hline \multirow{7}{*}{$\mathrm{CaCO}_{3}$} & Achatina achatina & Calcination & $400-600^{\circ} \mathrm{C}$ & 4 hours & FTIR and XRD & [34] \\
\hline & $\begin{array}{c}\text { Archachatina } \\
\text { marginata }\end{array}$ & Calcination & $320-670^{\circ} \mathrm{C}$ & 3 hours & EDX and XRF & {$[35]$} \\
\hline & Achatina fulica & Calcination & $50^{\circ} \mathrm{C}$ & 48 hours & AAS & {$[36]$} \\
\hline & Lanistes varicus & Calcination & $400-600^{\circ} \mathrm{C}$ & 4 hours & FTIR and XRD & {$[34]$} \\
\hline & Bellamya Javanica & Calcination & $1000^{\circ} \mathrm{C}$ & 2 hours & AAS & [37] \\
\hline & Pila ampullicea & Calcination & $470^{\circ} \mathrm{C}$ & 2 hours & $\mathrm{XRF}$ & {$[38]$} \\
\hline & $\begin{array}{c}\text { Pomacea } \\
\text { canaliculata }\end{array}$ & Calcination & $900^{\circ} \mathrm{C}$ & 3 hours & AAS and UV-VIS & [39] \\
\hline \multirow{4}{*}{$\begin{array}{c}\text { Other } \\
\text { Minerals }\end{array}$} & Achatina achatina & \multirow{4}{*}{ - } & \multirow{4}{*}{ - } & \multirow{4}{*}{-} & \multirow{4}{*}{ AAS } & \multirow{4}{*}[27-28,40]{} \\
\hline & $\begin{array}{c}\text { Archachatina } \\
\text { marginata }\end{array}$ & & & & & \\
\hline & Achatina fulica & & & & & \\
\hline & Limicolaria $s p$ & & & & & \\
\hline
\end{tabular}

* AAS (Atomic Absorption Spectrophotometer); EDX (Energy Dispersive X-Ray Spectroscopy); FTIR (Fourier Transform Infrared); XRD (X-Ray Diffraction); XRF (X-Ray Fluorescence); UV-VIS (UV Visible)

\subsubsection{Chitin and chitosan compounds.}

Analysis of chitin and chitosan compounds needs to be treated first, namely the separation of other compounds, such as protein and mineral content, and acetyl groups' removal to transforming chitin compounds into chitosan. Two ways can be used, namely chemically or enzymes. These methods involve deproteinized, demineralized, decolorization, and deacetylation processes that differ if the chemical method uses chemical solvents and the enzyme method, using microbes [41,42]. 
The method for treating chitin and chitosan compounds used is the chemical method. At the stage of the process of several gastropod class snail shells showed the difference in solvent concentration, temperature, and time used by each researcher. The process of deproteinization, demineralization, decolorization, and deacetylation can be done by stirring, heating at a high temperature $>100{ }^{\circ} \mathrm{C}$, and soaking alone without stirring. Research conducted by Kaewboonruang et al. [33] showed that the stirring process had better and optimum results compared to high-temperature heating and soaking without stirring. The same result was shown in a study by Maya et al. [31] that the greatest yield chitin and chitosan production of Achatina fulica shells used reflux plus water bath and magnetic stirrer.

The deproteinization process aims to remove protein, and demineralization removes the main minerals $\mathrm{CaCO}_{3}$ and $\mathrm{Ca}_{3}\left(\mathrm{PO}_{4}\right)_{2}$ (small amounts) contained in the shells of snails [24]. According to Sugita et al. [41], the efficiency of deproteinization and demineralization depends not only on the concentration of base (deproteinized), acid (demineralized), and temperature but also on the species of chitin source. In addition, based on the study of Oyekunle et al. [43] Regarding the process during demineralization, it shows that the smaller particle size of the snail shell powder is $300-600 \mu \mathrm{m}$, making the process of decreasing the $\mathrm{Ca}^{2+}$ concentration faster in the first 5 minutes. The chemical deacetylation process can be done by using a strong base of $\mathrm{NaOH}$ or $\mathrm{KOH}$. But the use of $\mathrm{KOH}$ can break the strong hydrogen bonds between chitin. Therefore in research, the use of $\mathrm{NaOH}$ solvent is more often used. Long deacetylation time with high temperature will cause a decrease in the yield and molecular weight of chitosan [41].

Instrument analysis for these two compounds can be seen in Table 1. Most of the instruments used are spectrophotometry Fourier Transform Infrared (FTIR). This method can be used simultaneously, reduces the risk of contamination due to a long work process, and minimizes the use of solvents in the analysis, and can be used for qualitative and quantitative analysis.

\subsubsection{Mineral compounds.}

The snail shell contains many mineral compounds, with the major compound being $\mathrm{CaCO}_{3}$. The compounds' method treats $\mathrm{CaCO}_{3}$ mainly through a calcination process at high temperatures ranging from $320-1200{ }^{\circ} \mathrm{C}$. Mineral $\mathrm{CaCO}_{3}$ is present in three phases, namely aragonite, calcite, and vaterite. Each of these phases has different properties. At room temperature, calcite is a stable phase, while vaterite and aragonite are metastable phases that can be transformed into a stable phase (calcite). These materials can be made as biomaterials for medical applications [38]. Thermodynamically calcite is a polymorph of $\mathrm{CaCO}_{3}$, the most stable at pressure and room temperature. Aragonite will change to calcite at a temperature of $380-470{ }^{\circ} \mathrm{C}$ [38]. It is known that the optimum temperature of the total $\mathrm{CaCO}_{3}$ phase conversion of calcite is in the range $380-600{ }^{\circ} \mathrm{C}$, but just like chitin and chitosan compounds, the efficiency of $\mathrm{CaCO}_{3}$ is also influenced by the species [41].

Analysis of instruments for mineral compounds can be seen in Table 2. Most of the instruments used are FTIR, AAS (Atomic Absorption Spectrophotometer), and XRF (X-Ray Fluorescence). AAS is particularly appropriate for the analysis of mineral and metal compounds at low concentrations [44]. XRF is a method of analysis that does not destroy the sample [45]. These three instruments are effective for analyzing qualitative and quantitative data on mineral and metal compounds. 


\subsection{Chemical compounds' content and benefits.}

\subsubsection{Chitin and chitosan content.}

Analysis of the content of chitin and chitosan compounds from several gastropod class snail shell species is shown in Table 3 . Chitin is the second-largest polysaccharide in nature after cellulose. Chitin is a poly [2-acetamido-2-deoxy- $\beta$ - $(1,4)$-D-glucopyranose] compound with the molecular formula $\left(\mathrm{C}_{8} \mathrm{H}_{13} \mathrm{NO}_{5}\right) \mathrm{n}$. Through a chemical process that involves deproteinization, demineralization, decolorization, and deacetylation of chitin compounds transformed into chitosan $\left(\mathrm{C}_{6} \mathrm{H}_{11} \mathrm{NO}_{4}\right) \mathrm{n}$ by removing acetyl groups $[23,41]$.

Chitin and chitosan in the health sector are useful as antibacterial agents. The results of the chitosan test from the shell Achatina fulica show that at an optimum concentration of 500 ppm an inhibitory power occurs of $34.33 \mathrm{~mm}$ against Staphylococcus aureus [8] and test data with a concentration of 300-700 ppm for diabetic ulcer patients caused by bacteria Staphylococcus aureus also show a sensitive reaction [46]. Another study also showed that if the cotton cloth coated with chitosan acetate Achatina fulica, the longer the immersion, the greater the activity against bacteria Staphylococcus aureus [47]. Based on the research of Yuvaraj et al. [48], $\mathrm{CaCO}_{3}$ from Pomacea canaliculata combined with chitosan from Periplaneta americana has antimicrobial benefits. The results showed that the combination of these two compounds could inhibit the growth of Escherichia coli, Pseudomonas aeruginosa, Bacillus subtilis, Bacillus licheniformis. And as a single compound, these two compounds also have potential as antimicrobials.

In the industrial world, chitosan is useful as a bioabsorbent. The research by Poerwati et al. [49] states that chitosan from the shell Achatina fulica can remove the color from liquid waste from the dyeing of the textile industry with a percentage of $88.05 \%$ with stirring for 72 hours. Chitosan from the shell of Achatina fulica also has the ability to adsorb methylene blue dye by $85.05 \%$ with a contact time of 6 hours [18]. In addition to absorbing the chitosan color from this species, it is useful as a heavy metal absorber. At the size of 250 microns, chitosan can absorb heavy metals by $95.27 \%$, and at the size of 355 microns, $96.18 \%$ with a mass of 9 grams of chitosan. The optimum adsorption capacity was obtained in chitosan measuring 250 microns [24]. As well as studies were done by Nitase et al. [50], chitosan Pila ampullaceal has an adsorption capacity of $0.355 \mathrm{mg} \mathrm{g}^{-1}$ with a contact time between adsorbent and adsorbate for 240 minutes.

The following data for chitin and chitosan are listed in percentage values shown in Table 3.

Table 3. Chitin and chitosan content in snail shells of gastropod class.

\begin{tabular}{c|c|c} 
Species Name & Chitin $(\boldsymbol{\%})$ & Chitosan $(\%)$ \\
\hline Land Snail & & \\
\hline Achatina achatina & Unknown & $46.37^{[30]}$ \\
\hline Achatina fulica & $13.42^{[31]}$ & $67.16^{[31]}$ \\
\hline Archachatina marginata & Unknown & $35.85^{[30]}$ \\
\hline Freshwater Snail & & \\
\hline Nerita crepidularia & $35.43^{[14]}$ & $44.29^{[14]}$ \\
\hline Pila ampullacea & $46.41^{[32]}$ & $39.83^{[32]}$ \\
\hline Pomacea canaliculata & $1.99^{[33]}$ & $42.56^{[33]}$
\end{tabular}




\subsubsection{Mineral content.}

Analysis of the mineral compound of $\mathrm{CaCO}_{3}$ from several species of gastropod class snail shells is shown in Table 4 and other minerals Table 5. CaCO3 compound is commonly used in the pharmaceutical world as an antacid because of its ability to neutralize stomach acid. Research conducted by Siregar et al. [39] makes hydroxyapatite biomaterial $\left[\mathrm{Ca}_{10}\left(\mathrm{PO}_{4}\right)_{6}(\mathrm{OH})_{2}\right]$ sourced from $\mathrm{CaCO}_{3}$ from snail shell waste Pomacea canaliculata.

Hydroxyapatite itself is a biomaterial that is used for bone graft with bone implants which is useful for repairing damaged tissues and broken bones. Currently, two types of hydroxyapatite morphology have been found, namely hydroxyapatite dense and porous. Porous hydroxyapatite has advantages due to its good pore conditions for nutrient transport, tissue infiltration, and vascularization [39]. The analysis showed that the ratio of calcium and phosphorus for hydroxyapatite was dense and porous 1.677 and 1.673, respectively, so that the hydroxyapatite approached the standard hydroxyapatite. The compressive strength of hydroxyapatite dense and porous is $19.61 \mathrm{MPa}$ and 9.807 MPa, respectively, so hydroxyapatite is porous more effective in nutrient infiltration to repair bone damage [39]. Not only as a bone graft, hydroxyapatite is also useful for the removal of $\mathrm{Pb}$ (II) [51].

Calcium carbonate can also be converted into calcium phosphate as research from Bonou et al. [52] using the shells of species, Achatina achatina calcium phosphate compounds can be useful as bone repair surgery. According to the results of other studies also stated that $\mathrm{CaCO}_{3}$ from the species Pomacea canaliculata can be useful as an absorber of heavy metal cardium [53] and bichromate ion from the species Pila ampullacea [54].

Table 4. Calcium Carbonate Content in Snail Shells of Gastropod Class

\begin{tabular}{c|c} 
Species Name & $\mathbf{C a C O}_{3}(\boldsymbol{\%})^{\mathbf{a}}(\mathbf{m g} / \mathbf{g})^{\mathbf{b}}$ \\
\hline Land Snail & $98.5^{\mathrm{a}[34]}$ \\
\hline Achatina achatina & $48.11-48.92^{\mathrm{b}[36]}$ \\
\hline Achatina fulica & $81^{\mathrm{a}[35]}$ \\
\hline Archachatina marginata & $98.75^{\mathrm{a}[34]}$ \\
\hline Laniste varicus & $67.80^{\mathrm{a}[37]}$ \\
\hline Freshwater Snail & $93,438^{\mathrm{a}[38]}$ \\
\hline Bellamya javanica & $48.02^{\mathrm{a}[39]}$
\end{tabular}

Table 5. Other Mineral Content in Snail Shell of Gastropods Class

\begin{tabular}{|c|c|c|c|c|c|c|c|c|}
\hline Species Name & $\begin{array}{c}\text { Zinc } \\
(\mathbf{m g} / \mathbf{l})\end{array}$ & $\begin{array}{c}\text { Cooper } \\
(\mathrm{mg} / \mathrm{l})\end{array}$ & $\begin{array}{c}\text { Manganese } \\
(\mathrm{mg} / \mathrm{l})\end{array}$ & $\begin{array}{c}\text { Iron } \\
(\mathbf{m g} / \mathbf{l})^{\mathbf{a}} \\
(\mathbf{m g} / \mathbf{1 0 0} \mathbf{g})^{\mathbf{b}}\end{array}$ & $\begin{array}{l}\text { Phospor } \\
\text { (mg/100 } \\
\text { g) }\end{array}$ & $\begin{array}{c}\text { Sodium } \\
(\mathbf{m g} / \\
100 \mathrm{~g})\end{array}$ & $\begin{array}{l}\text { Potassium } \\
(\mathrm{mg} / 100 \mathrm{~g})\end{array}$ & Ref. \\
\hline \multicolumn{9}{|l|}{ Land Snail } \\
\hline Achatina achatina & 9.85 & 6.47 & 4.31 & $251.23^{\mathrm{a}}$ & - & - & - & {$[27]$} \\
\hline Achatina fulica & 8.02 & 5.51 & 16.98 & $37.04^{\mathrm{a}}$ & - & - & - & [27] \\
\hline $\begin{array}{c}\text { Archachatina } \\
\text { marginata }\end{array}$ & 2.50 & 5.33 & 6.71 & $57.45^{\mathrm{a}}$ & - & - & - & {$[27]$} \\
\hline Limicolaria $s p$ & 6.30 & 4.46 & 1.99 & $208.58^{a}$ & - & - & - & {$[27]$} \\
\hline \multicolumn{9}{|l|}{ Freshwater Snail } \\
\hline $\begin{array}{c}\text { Bellamya } \\
\text { bengalensis }\end{array}$ & - & - & - & $300.10^{\mathrm{b}}$ & 1680.56 & 200.89 & 40.83 & {$[40]$} \\
\hline Melania tuberculata & - & - & - & $280.38^{\mathrm{b}}$ & 1440.98 & 230.08 & 50.72 & {$[40]$} \\
\hline
\end{tabular}

Analysis of other mineral compositions in the shells of the snails showed that all species had different levels. The sample Archatina archatina has the highest amount of iron value, which is $251.23 \mathrm{mg} / \mathrm{l}$, as shown in Table 5. Iron compounds are one of the most abundant metals on earth, which is ranked 9 and has benefits, such as iron (III) chloride as a coagulant 
in wastewater treatment especially in metal removal [27,28]. Data regarding levels of mineral compounds from gastropod snail shells can be seen in Table 4 and Table 5 is listed in $\mathrm{mg} / \mathrm{l}$ or $\mathrm{mg} / 100 \mathrm{~g}$.

\subsubsection{Proximate composition.}

In the gastropod snail shell, the data on the levels of proximate compounds that are owned is insufficiently large or called minor content data. An analysis of the various proximate compositions of different snail species is shown in Table 4. NFE (Nitrogen Free Extract) is known as a dissolved carbohydrate. The analysis shows that Archatina archatina has the highest carbohydrate value, one of which is influenced by the size of the snail, the largest compared to other types listed in the table. The high content of NFE can be added to several food ingredients to increase the carbohydrate content $[27,55]$.

The ash content aims to determine the carbon compounds and inorganic components in the form of salts and oxides in the shells of snails. Carbon can be useful as an absorber for gaseous precursors that produce odors, odors in wastewater, and canned garbage $[27,55]$.

The fiber content of each species increases the snail shell's strength, which affects the hardness of the snail shell [27,28]. Besides that, the environment can be useful as a medium for absorbing waste [55]. Data regarding the proximate composition of gastropod sp snail shells, which can be seen in Table 6 .

\begin{tabular}{c|c|c|c|c|c|c} 
Table 6. Proximate Composition in Snail Shell of Gastropods Class \\
Species Name & Protein $\mathbf{( \% )}$ & $\begin{array}{c}\text { Fiber } \\
(\mathbf{\%})\end{array}$ & Fat $(\mathbf{\%})$ & $\begin{array}{c}\text { Ash } \\
\mathbf{( \% )})\end{array}$ & $\begin{array}{c}\text { NFE } \\
(\mathbf{\%})\end{array}$ & Ref. \\
\hline Land Snail & & & & & & \\
\hline Achatina achatina & 0.12 & 4.06 & 0.79 & 2 & 93.04 & {$[28]$} \\
\hline Archachatina marginata & 0.42 & 3.37 & 0.75 & 10 & 5.46 & {$[28]$} \\
\hline Achatina fulica & 0.30 & 3.96 & 0.38 & 10 & 85.36 & {$[28]$} \\
\hline Limicolaria sp & 0.23 & 4.14 & 0.48 & 13 & 82.15 & {$[28]$}
\end{tabular}

\section{Conclusions}

The shells of freshwater and land snails from the gastropod class contain a wide variety of chemical compounds. Based on the results of several studies in snail shells, they contain major chemical compounds, that is, $\mathrm{CaCO}_{3}$, chitin, and chitosan. Where the highest content of these compounds came from Lanistes varicus for $\mathrm{CaCO}_{3}$ with concentration $98.75 \%$, chitin content from Pila amppulacea was $46.41 \%$, and from the deacetylation process of chitin, chitosan compounds were obtained, with the highest content come from the species Achatina fulica which was $67.16 \%$. Also, there are other minor compounds, such as minerals zinc, iron, copper, phosphorus, manganese, sodium, potassium, and proximate data. These compounds can be used as biomaterials that are useful in the world of health. Instruments for the analysis of chitin and chitosan compounds can use FTIR spectrophotometry and mineral compounds $\mathrm{CaCO}_{3}$ and other minerals. can use AAS and XRF

\section{Funding}

This research received no external funding.

\section{Acknowledgments}

This research has no acknowledgment. 


\section{Conflict Interest}

The author declares no conflict of interest.

\section{Reference}

1. Arpani; Maulana, F. Diversity and Abundance of Gastropods in the Rice Fields of Sungai Pinang Baru Village, Banjar Regency. Journal of Life Education, 2017, 3, 55-66, https://jurnal.stkipbjm.ac.id/index.php/JPH/article/view/478

2. Houndonougbo, M. F.; Chrysostome, C. A. A. M.; Odoulami, R. C.; Codjia, J. T. C. Snail shell as an efficient mineral feedstuff for layer hens: Effects and optimum rate. Livestock Research for Rural Development, 2012, 24.

3. Oyekunle, D. T.; Omoleye, J. A. New Process for Synthesizing Chitosan from Snail Shell. Journal of Physics: Conference Series, IOP Publishing 2019, https://doi.org/10.1088/1742-6596/1299/1/012089.

4. Christian, K. M.; Annick, E. N.; Siri, B. N.; Kingsley, E. Socio-Economic Perception of Snail Meat Consumption in Fako Division, South-West Region Cameroon. International Journal of Livestock Production (IJLP) 2019, 10, 143-151, https://doi.org/10.5897/IJLP2018.0543.

5. Ghosh, S.; Jung, C.; Rochow, V. B. M. Snail as Mini-Livestock: Nutritional Potential of Farmed Pomacea canaliculata (Ampullariidae). Agriculture and Natural Resources 2017, 51, 504-511, https://doi.org/10.1016/j.anres.2017.12.007.

6. Needham, S.; Smith, S. F. The Consumption of Fish and Fish Products in the Asia-Pacific Region Based on Household Surveys; RAP Publication: Bangkok, Thailand 2015; 70-72.

7. Nurhaeni; Ridhay, A.; Laenggeng, A. H. Optimization of Degree of Deacetylation of Chitosan Snail Shells (Pilla ampulaceae). Asian Journal of Chemistry 2019, 31, 2083-2086, https://doi.org/10.14233/ajchem.2019.22112.

8. Umarudin, U.; Surahmaida, S.; Alta, R .; Ningrum, R. S. Preparation, Characterization, and Antibacterial of Staphylococcus aureus Activity of Chitosan from Shell of Snail (Achatina fulica F.). Biota: Bio and Pend Bio 2019, 12, 22-31 http://dx.doi.org/10.20414/jb.v12i1.180.

9. Debnath, C.; Sahoo, L.; Haldar, A.; Datta, M.; Yadav, G. S.; Singha, A.; Bhattacharjee, J. Proximate and Mineral Composition of Freshwater Snails of Tripura, North-East India. Fish. Technol 2016, 53, 307-312.

10. Parveen, S.; Chakraborty, A.; Chanda, D. K.; Pramanik, S.; Barik, A.; Aditya, G. Microstructure Analysis and Chemical and Mechanical Characterization of the Shells of Three Freshwater Snail. ACS Omega 2020, 5, 25757-25771, https://dx.doi.org/10.1021/acsomega.0c03064.

11. Marcel, K. N.; Rosemonde, Y. E. S.; Patricia, K. A.; Alexandre, Z. B. F. G.; Ambroise, A. N.; Ernest, A. K. Evaluation of the Nutritional Potential of Snail (Achatina spp) Meat in Rat. European Scientific Journal 2020, 16, 111-121, http://dx.doi.org/10.19044/esj.2020.v16n12p111.

12. Firnanelty; Sugiarti, S.; Charlena. Synthesis Of HAp-Chitosan-PVA Composite as Injectable Bone Substitute Material. RJC 2017, 10, 570-576, http://dx.doi.org/10.7324/RJC.2017.1021465.

13. Asimeng, B. O.; Fianko, J. R.; Kaufmann, E. E.; Tiburu, E. K.; Hayford, C. F.; Anani, P. A.; Dzikunu, O. K. Preparation and Characterization of Hydroxyapatite from Achatina achatina Snail Shells: Effect of Carbonate Substitution and Trace Elements on Defluoridation of Water. Journal of Asian Ceramic Societies 2018, 6, 205-212, https://doi.org/10.1080/21870764.2018.1488570.

14. Palpandi, C.; Ramasamy, P.; Rajinikanth, T.; Vairamani, S.; Shanmugam, A. Extraction of chitin and chitosan from shell and D operculum of mangrove gastropod Nerita (Dostia) crepidularia Lamarck. International Journal of Medicine and Medical Sciences 2009, 1(5), 198-205.

15. Buddhika, R. B. J.; Rasangika, J. P. S.; Pathirana, W.; Wijayabandara, S. D.; Chinthaka, M. Pharmacopoeial Evaluation of Calcium Carbonate Deposits in Sri Lanka. Pharmaceutical Journal of Sri Lanka, 2011.

16. Kim, S. Competitive Biological Activities of Chitosan and Its Derivatives: Antimicrobial, Antioxidant, Anticancer, and Anti-Inflammatory Activities. International Journal of Polymer Science 2018, 1-13, https://doi.org/10.1155/2018/1708172.

17. Oyekunle, D. T.; Omoleye, J. A. Extraction, Characterization and Kinetics of Demineralised of Chitin Produced From Snail Shells of Different Particle Sizes Using 1.2 M HCL. International Journal of $\begin{array}{lllll}\text { Mechanical } \quad \text { Engineering 2011-2020, } & \text { 2019, }\end{array}$ http://www.iaeme.com/ijmet/issues.asp?JType=IJMET \&VType=10\&IType=1. 
18. Iget, R..; Nurhaeni; Ruslan; Puspitasari, D. J. Absorption of Methylene Blue Dyes Using Chitosan from Rice Conch Shell as A Biosorbent. KOVALEN Journal of Chemical Research 2019, 5, 214-221, https://doi.org/10.22487/kovalen.2019.v5.i2.12826.

19. Pighinelli, L.; Broqua, J.; Zanin, B. G.; Flach, A. M.; Mallmann, C.; Taborda, F. G. D.; Machado, L. E. L.; Alves, S. M. L.; Silva, M. M.; Dias, R. J. S. P. Methods of Chitin Production a Short Review, America Journal Biomed Science and Research 2019, 3, 307-314, https://doi.org/10.34297/AJBSR.2019.03.000682.

20. Basigsig, P. L. J. E.; Makiling, J. E. E.; Niog, C. J. T.; Sarmiento, N. B.; Masangcay, S. I. G. Golden Apple Snail Shell (Pomacea canaliculata) as Prospective Agent in Absorbing Lead (pb) in Water. Modern Chemistry 2019, 7, 1-4, https://doi.org/10.11648/j.mc.20190701.11.

21. Peter, O. I.; Adeyinka, O. J.; Akolade, R. A. Application of Snail Shell Chitosan as a Bioadsorbent in Removal of Copper (II) Ions from Wastewater. Earthline Journal of Chemical Science 2019, 2, 141-151, https://doi.org/10.34198/ejcs.2119.141151.

22. Samsi, A. N.; Asaf, R.; Sahabuddin, S.; Santi, A.; Wamnebo, M. I. Gastropods as A Bioindicator and Biomonitoring Pollution. An International Journal Aquaculture Society 2017, 9, 1-8, http://dx.doi.org/10.21534/ai.v18i1.42.

23. Pillai, C. K. S.; Paul, W.; Sharma, C. P. Chitin and Chitosan Polymers: Chemistry, Solubility and Fiber Information. Progress in Polymer Science 2009, 34, 641-678, https://doi.org/10.1016/j.progpolymsci.2009.04.001.

24. Marang, R. S. V; Andhika, B.; Syauqiah, I. Utilization of Chitosan from Snail Shell Waste (Achatina fulica) as Heavy Metal Zinc (Zn) Adsorbent. Conversion 2016, 5, 24-29, http://dx.doi.org/10.20527/k.v5i1.4775

25. Beesley, P. L.; Ross, A.; Wells, G. J. Mollusca: The Southern Synthesis. Fauna of Australia Volume 5.; CSIRO Publishing: Collingwood, Australia, 1998; pp. 14-42.

26. Isnaningsih, N. R.; Listiawan, D. A. Keong dan Kerang dari Sungai-Sungai di Kawasan Karst Gunung Kidul. $\begin{array}{llllll}\text { Journal Zoo } & \text { Indonesia, } & \mathbf{2 0 1 1}, & 20, & 1-10, & \text { http://e- }\end{array}$ journal.biologi.lipi.go.id/index.php/zoo_indonesia/article/download/2342/2108.

27. Jatto, E. O.; Asia, O.; Medjer, W. E. Proximate and Mineral Composition of Different Species of Snail Shell. The Pacific Journal of Science and Technology 2010, 11, 416-419.

28. Jatto, E. O.; Asia, O.; Egharevba, F. Kinetic Studies of Wastewater Treatment from Pharmaceutical Industry using Snail Shell Powder. International Journal of Advanced Research 2013, 1, 47-56.

29. Brigham, C. J. Chitin and Chitosan: Sustainable, Medically Relevant Biomaterials. International Journal of Biotechnology for Wellness Industries 2017, 6, 41-47, https://doi.org/10.6000/1927-3037.2017.06.02.1.

30. Agoha, E. E. C.; Mazi, E.A. Biopolymers from African Giant Snail Shells Waste: Isolation and Characterization. In: World Congress on Medical Physics and Biomedical Engineering, IFMBE Proceedings, Abia State University Department of Food Science and Technology Umuahia, Nigeria, September 7-12, 2009; Dössel O., Schlegel WC (eds); Springer-Verlag Berlin Heidelberg, Munich, Germany, 2009, https://doi.org/10.1007/978-3-642-03900-3_71.

31. Maya, S. M. G.; Putri, R. R. F. A.; Sahara, A.; Ashari, G. A.; Zaky, A.; Adrianto, D. Comparison of Methods for Glucosamine Production from Achatina fulica Shells Waste. Current Biochemistry 2017, 4, 1-8, https://doi.org/10.29244/cb.4.1.15-22.

32. Ramdani, AH; Ningrum, RS Effectiveness of Eco-absorbent Modified Chitosan Membrane from Pila ampullacea as Urban Water Filter to Provide Healthy Sanitary Water in Kediri, IOP Conf. Series: Earth and Environmental Science 3, IOP Publishing 2019, https://doi.org/10.1088/1755-1315/308/1/012036.

33. Kaewboonruang, S.; Phatrabuddha, N.; Sawangwong, P.; Pitaksanurat, S. Comparative Studies on the Extraction of Chitin - Chitosan from Golden Apple Snail Shells at the Control Field. IOSR Journal of Polymer and Textile Engineering 2016, 3, 34-41, https://doi.org/10.9790 / 019X-03013441.

34. Osseni, S.; Bonou, S.; Sagbo, E.; Ahouansou, R.; Agbahoungbata, M.; Neumeyer, D.; Verelst, M.; Mauricot, R. Synthesis of Calcium Phosphate Bioceramics Based on Snail Shells: Towards a Valorization of Snail Shells from Republic of Benin. American Journal of Chemistry 2018, 8, 90-95. https://doi.org/10.5923/j.chemistry.20180804.02.

35. Kolawole, M. Y.; Aweda, J. O.; Abdulkareem, S. Archachatina marginata bio-shells as reinforcement material in metal matrix composites. International Journal of Automotive and Mechanical Engineering 2017, 4, 4068-4079, https://doi.org/10.15282/ijame.14.1.2017.18.0328.

36. Ademolu, K.; Precious, O.; Ebenso, I.; Baratunde, I. Morphometrics and Mineral Composition of Shell Whorls In Three Species of Giant African Snails from Abeokuta, Nigeria. Folla Malacologica 2016, 24, 8184, http://dx.doi.org/10.12657/folmal.024.013. 
37. Charlena; Sugeng, B.; Astuti, L. P. Hydroxyapatite Synthesis from Garden Snail (Bellamya javanica) Using Precipitation Double Stirring Simultaneous Method. Prosiding SEMIRATA 2015 bidang MIPA BKS-PTN Barat Universitas Tanjungpura, 284-293, https://jurnal.untan.ac.id/index.php/semirata2015/article/view/14236/12728

38. Delvita, H.; Djamas, D.; Ramli. The Effect of Calcination Temperature Variations on the Characteristics of Calcium Carbonate $\left(\mathrm{CaCO}_{3}\right)$ in Rice Snail Shells (Pila ampullacea) in Pasaman Regency. Journal of Pillar of Physics 2015, 6, 17-24, http://ejournal.unp.ac.id/students/index.php/fis/article/viewFile/1933/1540.

39. Siregar, R. F.; Sulistyowati, E. Characteristics of Porous Hydroxyapatite from Precursors of Rice Conch Shells and Porogeneous Materials of Breadfruit. Exergy Journal of Chemical Engineering Study Program UPN Veteran Yogyakarta 2019, 16, 59-63, https://doi.org/10.31315/e.v16i2.3082.

40. Baby, R. L.; Hasan, I.; Kabir, K. A.; Naser, M. N. Nutrient Analysis of Some Commercially Important Molluscs of Bangladesh. Journal of Scientific Research 2010, 2, 390-396, https://doi.org/10.3329/jsr.v2i2.3362.

41. Sugita, P .; Wukirsari, T .; Sjahriza, A .; Wahyono, D. Kitosan: Sumber Biomaterial Masa Depan; IPB Press: Bogor, Indonesia 2009: pp. 23-31.

42. Nurhaeni; Ridhay, A.; Laenggeng. Depolymerization of chitosan from snail (Pilla ampullacea) field shell using $\alpha$-amylase. IOP Conf. Series: Journal of Physics, IOP Publishing 2019, https://doi.org/10.1088/1742$6596 / 1242 / 1 / 012005$.

43. Oyekunle, D. T.; Omoleye, J. A. Effect of Particle Sizes On The Kinetics of Demineralised of Snail Shell For Chitin Synthesis Using Acetic Acid. Heliyon 2019, 5, 1-7. https://doi.org/10.1016/j.heliyon.2019.e02828

44. Khopkar, S.M. Basic Concepts of Analytical Chemistry, 3rd Edition.; New Academic Science: London, United Kingdom, 2008; pp. 308-324.

45. Sari, K.R. Potensi Mineral Batuan Tambang Bukit 12 Dengan Metode XRD, XRF dan AAS. Eksakta 2016, 2, 13-23, http://ejournal.unp.ac.id/index.php/eksakta/article/view/7478.

46. Umarudin, U.; Surahmaida, S. Isolation, Identification, and Antibacterial Test Of Gastropod Chitosan of Snail Shell (Achatina fulica) Against Staphylococcus aureus From Diabetic Ulcer. Simbiosa Journal 2019, 8, 37 49. http://dx.doi.org/10.33373/sim-bio.v8i1.1894

47. Rismawati, R.; Hasri, H.; Sudding, S. Kitosan Asetat Cangkang Bekicot (Achatina Fulica) Sebagai Antibakteri Pada Kain Katun. Sainsmat : Jurnal Ilmiah Ilmu Pengetahuan Alam 2020, 9(2), 45-46, https://ojs.unm.ac.id/jsainsmat/article/view/14190.

48. Yuvaraj, D.; Gnanasekaran, R.; Iyyapan, J.; Subahashini, I.; Nandhini, S.; Jayasudha, M.; Shaleni, R.; Shyam, M. Production of Antimicrobial Adhesive. Journal of Environmental Biology 2019, 40, 812-816. http://doi.org/10.22438/jeb/40/4(SI)/JEB_26

49. Poerwati, S. Pemanfaatan Cangkang Bekicot dalam Pengolahan Limbah Cair Hasil Pewarnaan Industri Tekstil. Journal of Health Research: FORIKES VOICE 2011, 2(1), 16.https://suaraforikes.webs.com/volume2\%20nomor1.pdf.

50. Nitase, M.; Solle, H. R. L.; Ledo, M. E. S. Preparasi Kitosan dari Cangkang Keong Sawah (Pila ampullacea) asal Persawahan 'Aerbauk’ Desa Oesao, Kabupaten Kupang untuk Adsorpsi Timbal (II). Journal of MIPA UNNES 2018, 41(2), 96-104, https://journal.unnes.ac.id/nju/index.php/JM/article/view/18085.

51. Hariani, P. L.; Riyanti, F.; Fatma, F.; Rachmat, A.; Herbanu, A. Removal of Pb (II) using Hydroxyapatite from Golden Snail Shell (Pomacea canaliculata L.) Modified with Silica. Molecule 2020, 15, 130-139, https://doi.org/10.20884/1.jm.2020.15.2.641.

52. Bonou, S.; Sagbo, E.; Aubry, C.; Charvillat, C.; Nissan, B. B.; Cazalbon, S. Conversion of Snail Shells (Achatina achatina) Acclimatized in Benin to Calcium Phosphate for Medical and Engineering Use. Journal of The Australian Ceramic Society 2020, 55, 1177-1186, https://doi.org/10.1007/s41779-019-00334-6.

53. Nopriansyah, E.; Baehaki, A.; Noprianti, R. Pembuatan Serbuk Cangkang Keong Mas (Pomacea Canaliculata L.) Serta Aplikasinya Sebagai Penjernih Air Sungai Dan Pengikat Logam Berat Kadmium. FishtecH : Jurnal

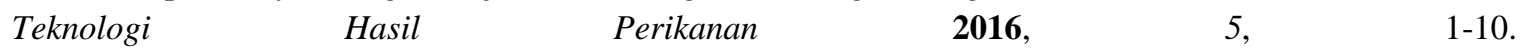
https://ejournal.unsri.ac.id/index.php/fishtech/article/view/3513/1857.

54. Fatimah, I.; Aulia, G.R.; Puspitasari, W.; Nurlilah, R.; Sopia, L.; Herianto, R. Microwave-synthesized hydroxyapatite from paddy field snail (Pila ampullacea) shell for adsorption of bichromate ion. Sustainable Environment Research 2018, 28, 462-471, https://doi.org/10.1016/j.serj.2018.10.003.

55. Jatto, E. O.; Asia, O.; Egharevba, F.; Ewansiha, C. J. Kinetics Studies of The Treatment of Wastewater From Brewery Industry, Using Powdered Snail Shell. Water-Energy Nexus 2020, 3, 95-102, https://doi.org/10.1016/j.wen.2020.06.001. 